\title{
Management of Brinjal Shoot and Fruit Borer (Leucinodes orbonalis Guenee) Using Eco-Friendly IPM Strategies in Farmer's Fields of Krishna District of Andhra Pradesh, India
}

\author{
P. Sudha Jacob $^{1 *}$ and Revathi ${ }^{2}$ \\ ${ }^{1}$ Krishi Vigyan Kendra, Ghantasala, Andhra Pradesh, India \\ ${ }^{2} S$ V Agricultural College, Tirupati, Andhra Pradesh, India \\ *Corresponding author
}

\begin{tabular}{|l|}
\hline Ke y w o r d s \\
Brinjal, Shoot and \\
fruit borer, IPM, \\
Pheromone traps, \\
Yield and Net \\
income
\end{tabular}

A B S T R A C T

On farm trials in ten locations were conducted to evaluate efficacy of eco-friendly IPM strategies with emphasis on use of pheromone traps for management of brinjal shoot and fruit borer (Leucinodes orbonalis Guenee) and to create awareness among the farming community on brinjal fruit and shoot borer management during rabi, 2014-15 to 2017-18 in the farmer's fields in Krishna District of Andhra Pradesh. By adoption of eco-friendly IPM practices in all the four years, the shoot damage was reduced on an average by 4.02 per cent compared to 9.19 per cent in farmers practice. The fruit damage on an average was also reduced by 16.42 per cent compared to 31.55 per cent in farmers practice. The total moth trap catches per trap per season on an average was 86.64 helping in reducing the pest load, damage and enabled in correct decision making in application of insecticides. This has resulted in reduction in the average cost of cultivation by Rs. 17089.00 per hectare and the average net income was improved by Rs. 51009 per hectare compared to the farmers practice. The average yield levels improved by 12.94 per cent compared to farmers practice (35.7 qt/ha) and giving a clear message that adoption of IPM practices with emphasis on pheromone traps helped in reducing the pest levels, damage and improving yield; helps in improving the decision making capacity and net income levels to the resource poor farmers.

\section{Introduction}

Brinjal eggplant (Solanum melongena L.) is an important, highly cosmopolitan and popular vegetable grown as poor man's crop in India. It contributes 8.3 per cent of the total vegetable production of the country. In India, area under brinjal cultivation in 2013-14 was 0.71 million ha with productivity of $19.1 \mathrm{t} / \mathrm{ha}$ and in Andhra Pradesh, it is cultivated in 0.058 million hectare with productivity of 20.0 t/ha (Indian Horticulture database, 2015). Different insect pests attack brinjal from the time of planting till its harvest. Some important insect pests are brinjal shoot and fruit borer (BSFB) (Leucinodes orbonalis), coccinellid beetle (Epilachna vigintioctopunctata), leafhopper (Amrasca 
bigutulla bigutulla), aphid (Aphis gossypii) and whitefly (Bemisia tabaci) (Latif et al., 2009).

Among the various pests which hinder the realization of the yield potential, the most destructive and serious pest is brinjal shoot and fruit borer (BSFB), L. orbonalis Guenee (Lepidoptera: Pyraustidae) (Latif et al., 2010; Chakraborti and Sarkar, 2011). It is monophagous and remained a major pest of brinjal in all growing areas (Dutta et al., 2011). The pest is more prevalent in areas having hot and humid climate (Srinivasan, 2009). The yield losses may reach up to 85 to 90 per cent (Misra, 2008; Jagginavar et al., 2009).

The larva soon after emergence causes dead hearts by boring into the petiole and midrib of leaves, tender shoots (CABI, 2007; Alpureto, 1994 and AVRDC, 1998). On appearance of the flowers and fruits in the later stages, the larvae cause severe loss to the economic parts. The larvae, after hatching, bore inside fruit and the minute entrance hole is closed by the excreta of feeding larvae (Alam et al., 2006). But once fruit setting is initiated, shoot infestations become negligible (Kumar and Dharmendra, 2013) or completely disappear (Naqvi et al., 2009). Larvae feed on the mesocarp of fruit and the feeding and excretion result in fruit rotting (Neupane, 2001), making it unfit for human consumption (Baral et al., 2006). On an average, a larva can infest 4 - 7 fruits during its life span (Jayaraj and Manisegaran, 2010). Infestation by this pest results in lowering the vitamin $\mathrm{C}$ content up to 80 per cent in infested brinjal fruit (Sharma, 2002).

Since this pest is an internal feeder, formulating an adoptable management strategy on a wider scale is a difficult task. Even though several cultural measures were developed for containing this monophagous pest, no single measure is sufficient to efficiently manage this pest to a satisfactory level and thus farmers rely highly on chemical pesticides owing to their ease in adoption and adoptability in wider areas with varied frequency of application to produce damage free marketable produce.

Nearly $90 \%$ of the Indian farmers apply chemical pesticides in brinjal cultivation and the number of pesticide sprays range from 10 to 28 thus, spending a significant part of the cost of cultivation mainly towards chemical pesticide-based plant protection. Paradoxically, the brinjal farmers in India are resource poor and mainly belong to small, medium and marginal groups, who depend on this crop as an important source of income. This contradictory and opposing scenario of poor farmers extensively spending on chemical control of BSFB is a serious concern which demands urgent intervention by modern biology to mitigate the problem of BSFB (Vageesh babu et al., 2014). The current strategy of farmers is not only non-sustainable but, if continued, it will adversely affect consumers and the profitability of farmers threatening its cultivation.

Since employment of single strategy led to several adverse effects with variable efficacy levels, promotion of adoptable strategies in an integrated approach is the need of the hour to contain the monophagous internal borer. Such integrated pest management practices need to be promoted for adoption at field level on a wider scale with less reliance on pesticides. Use of pheromone traps for monitoring and mass trapping in combination with other techniques to bring down pest infestations can help in ensuring growth of healthy crops. Thus, an attempt was made to evaluate use of pheromone traps as major component of IPM with other techniques for the control of $L$. orbonalis in the farmers' fields. 


\section{Materials and Methods}

The present investigation was carried out in the farmers' fields of adopted villages of KVK, Ghantasala in Mopidevi mandal of Krishna district for four years from 2014-15 to 2017-18, where farmers cultivate brinjal in large area during rabi season. On farm trials were conducted in 10 selected farmers' fields with an objective to evaluate the performance of integrated pest management practices with emphasis on the use of pheromone traps for monitoring and mass trapping of brinjal fruit and shoot borer so that the same package may be popularized among the farming community with less dependence on pesticides.

T1: IPM with emphasis on use of pheromone traps

Collection and destruction of infested plant parts

Use of pheromone traps @ 50/ha for monitoring and mass trapping of male moths Need based application of insecticides

\section{T2: Farmers practices (Non IPM)}

Use of only insecticides for management of BSFB

Each treatment was imposed in $0.4 \mathrm{Ha}$ with brinjal MHB-52 and US-172 hybrids. Recommended package of practices were followed for raising the crop. For monitoring and mass trapping of male moths of BSFB, 50 WOTA traps with lucin lures (supplied by Pest Control India, Bangalore) were used at equal distance in the field. The traps were installed 30 days after transplanting of brinjal at $30 \mathrm{~cm}$ above the crop canopy. The traps were fixed on bamboo poles. The pheromone of BFSB consists of a mixture of (E)-11hexadecenyl acetate and (E)-11-hexadecen-1$\mathrm{ol}$, in a mixture of 10:1 to $100: 1$. Pheromone sample of 2-3 mg were impregnated on the inner surface of a plastic tube, when baited in a suitable trap and placed in the field can attract male moths continuously for up to 6 weeks (Talekar, 2002). The lures were changed at an interval of 45 days as recommended. Insecticides viz., profenophos, novaluron, flubendiamide and thiodicarb were sprayed at recommended doses for management of the pest infestation and fruit damage.

The data on infested shoot was recorded by direct count but percentage of infested fruits was calculated by using the following formula. For calculating the fruit infestation and yield per hectare, fruits after harvesting, the healthy and infested fruits were sorted out. The weight of healthy and infested fruits of each plot for each treatment was noted separately. The percent fruit infestation was calculated using the following formula:

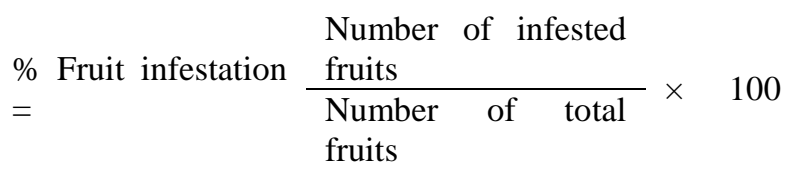

\section{Results and Discussion}

The results indicate (Table 1) that adoption of IPM module with emphasis on collection and destruction of infested plant parts viz., infested shoot in the early stages of the crop growth and damaged fruits in the later stages helped in reduction of pest population buildup and thereby the shoot and fruit damage. Farmers prefer high yielding private hybrids for getting higher net returns, which are fast growing, fertilizer responsive and less tolerant to pest's infestation. In 2014-15 in the IPM plot, the per cent shoot damage was 4.67 per cent while, fruit damage was 10 and in the farmers practice it was 10.8 per cent followed by 38 per cent, respectively, wherein only chemical insecticides were sprayed indiscriminately. In IPM plot, the fruit yield was $329.5 \mathrm{qt} / \mathrm{ha}$ with a 13.8 per cent increase over farmers practices 
(289.5 q/ha). In 2015-16 in the IPM plot, the per cent shoot damage was 3.12 per cent while, fruit damage was 13 and in the farmers practice it was 7.87 per cent followed by 25 per cent, respectively. In the IPM plot, the fruit yield was $350.5 \mathrm{qt} / \mathrm{ha}$ with a 12.3 percent increase over farmers practices (312 q/ha). In 2016-17 in the IPM plot, the per cent shoot damage was 4.96 per cent while, fruit damage was 20.2 and in the farmers practice it was 9.2 per cent followed by 34.2 per cent, respectively. In the IPM plot, the fruit yield was $213 \mathrm{qt} / \mathrm{ha}$ with a 14.4 per cent increase over farmers practices (186.25 q/ha). In 201718 in the IPM plot, the per cent shoot damage was 3.34 per cent while, fruit damage was 16.5 and in the farmers practice, it was 8.9 per cent followed by 29 per cent, respectively. In the IPM plot, the fruit yield was $337.5 \mathrm{qt} / \mathrm{ha}$ with a 11.25 per cent increase over farmers practices (300 q/ha).
Pheromone trap catch of adult male moths of brinjal shoot and fruit borer, $L$. orbonalis

Pheromone traps were used in the IPM module to trap the adult moths present in the crop environment to prevent the egg laying, so that the buildup of the pest population and subsequent infestation to the shoots and fruits can be minimized with much less use of chemical insecticides. In the present investigation pheromone traps @ 50/ha was used and results indicate that the use of pheromone traps not only helped in monitoring the pest status but also helped in attracting large number of male moths and in reducing the pest damage in all the years. Monitoring of moth activity can be used as a source of information to initiate pest management practices (Fig. 1 and 2).

Table.1 Details of the brinjal crop yields obtained and shoot and fruit damage

\begin{tabular}{|c|c|c|c|c|c|c|c|c|c|}
\hline \multirow[t]{2}{*}{ Year } & \multirow[t]{2}{*}{ Variety } & \multirow[t]{2}{*}{$\begin{array}{c}\text { No. of } \\
\text { Farmers }\end{array}$} & \multicolumn{2}{|c|}{ Yield (q/ha) } & \multirow{2}{*}{$\begin{array}{c}\text { Increase } \\
\text { in yield } \\
(\%)\end{array}$} & \multicolumn{2}{|c|}{$\begin{array}{l}\text { Per cent shoot } \\
\text { damage }\end{array}$} & \multicolumn{2}{|c|}{$\begin{array}{c}\text { Per cent fruit } \\
\text { damage }\end{array}$} \\
\hline & & & Demo & Check & & Demo & Check & Demo & Local \\
\hline 2014-15 & US - 172 & 10 & 329.5 & 289.5 & 13.8 & 4.67 & 10.8 & 16.0 & 38.0 \\
\hline 2015-16 & US - 172 & 10 & 350.5 & 312.0 & 12.3 & 3.12 & 7.87 & 13.0 & 25.0 \\
\hline 2016-17 & US - 172 & 10 & 213.0 & 186.25 & 14.4 & 4.96 & 9.2 & 20.2 & 34.2 \\
\hline 2017-18 & MHB-52 & 10 & 337.5 & 300.0 & 11.25 & 3.34 & 8.9 & 16.5 & 29.0 \\
\hline
\end{tabular}

Table.2 Details of cost of cultivation, average gross and net income levels

\begin{tabular}{|c|c|c|c|c|c|c|c|c|}
\hline \multirow{2}{*}{ Year } & \multicolumn{2}{|c|}{$\begin{array}{c}\text { Average Cost of } \\
\text { cultivation (Rs./ha) }\end{array}$} & \multicolumn{2}{c|}{$\begin{array}{c}\text { Average Gross Return } \\
\text { (Rs./ha) }\end{array}$} & \multicolumn{2}{c|}{$\begin{array}{c}\text { Average Net Return } \\
\text { (Profit) }\end{array}$ (Rs./ha) } & \multicolumn{2}{|c|}{ BC ratio } \\
\cline { 2 - 10 } & Demonstration & $\begin{array}{c}\text { Local } \\
\text { Check }\end{array}$ & Demonstration & $\begin{array}{c}\text { Local } \\
\text { Check }\end{array}$ & Demonstration & $\begin{array}{c}\text { Local } \\
\text { Check }\end{array}$ & Demo & $\begin{array}{c}\text { Local } \\
\text { Check }\end{array}$ \\
\hline $\mathbf{2 0 1 4 - 1 5}$ & 127500 & 132500 & 442575 & 409500 & 315075 & 277000 & 3.47 & 3.34 \\
\hline $\mathbf{2 0 1 5 - 1 6}$ & 133575 & 148950 & 466575 & 412520 & 333000 & 263570 & 3.49 & 2.76 \\
\hline $\mathbf{2 0 1 6 - 1 7}$ & 129500 & 162580 & 394050 & 372500 & 264550 & 209920 & 3.04 & 2.29 \\
\hline $\mathbf{2 0 1 7 - 1 8}$ & 119225 & 134125 & 267000 & 240000 & 147775 & 105875 & 2.24 & 1.79 \\
\hline
\end{tabular}


Fig.1 Graph showing the relationship between pheromone trap catches and damage levels

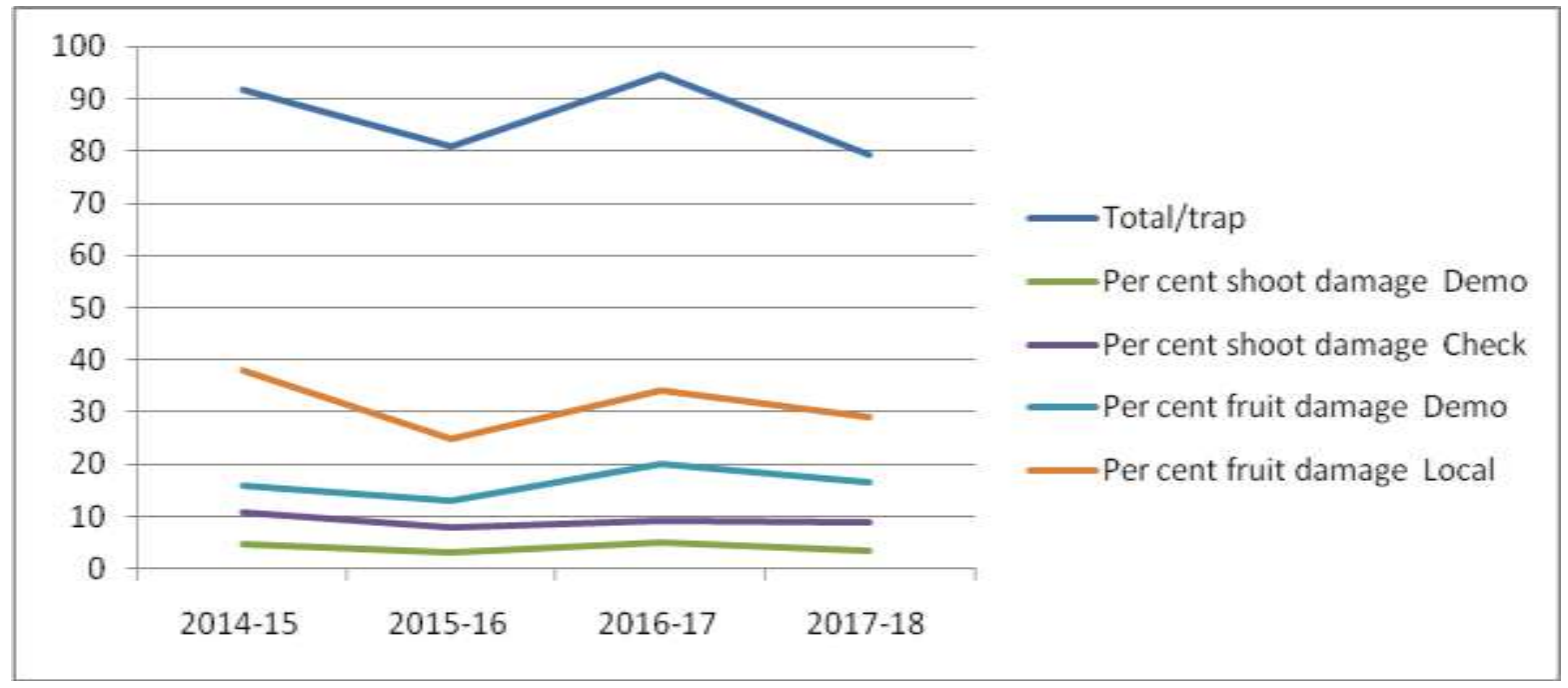

Fig.2 Graph showing the pheromone trap catches week wise

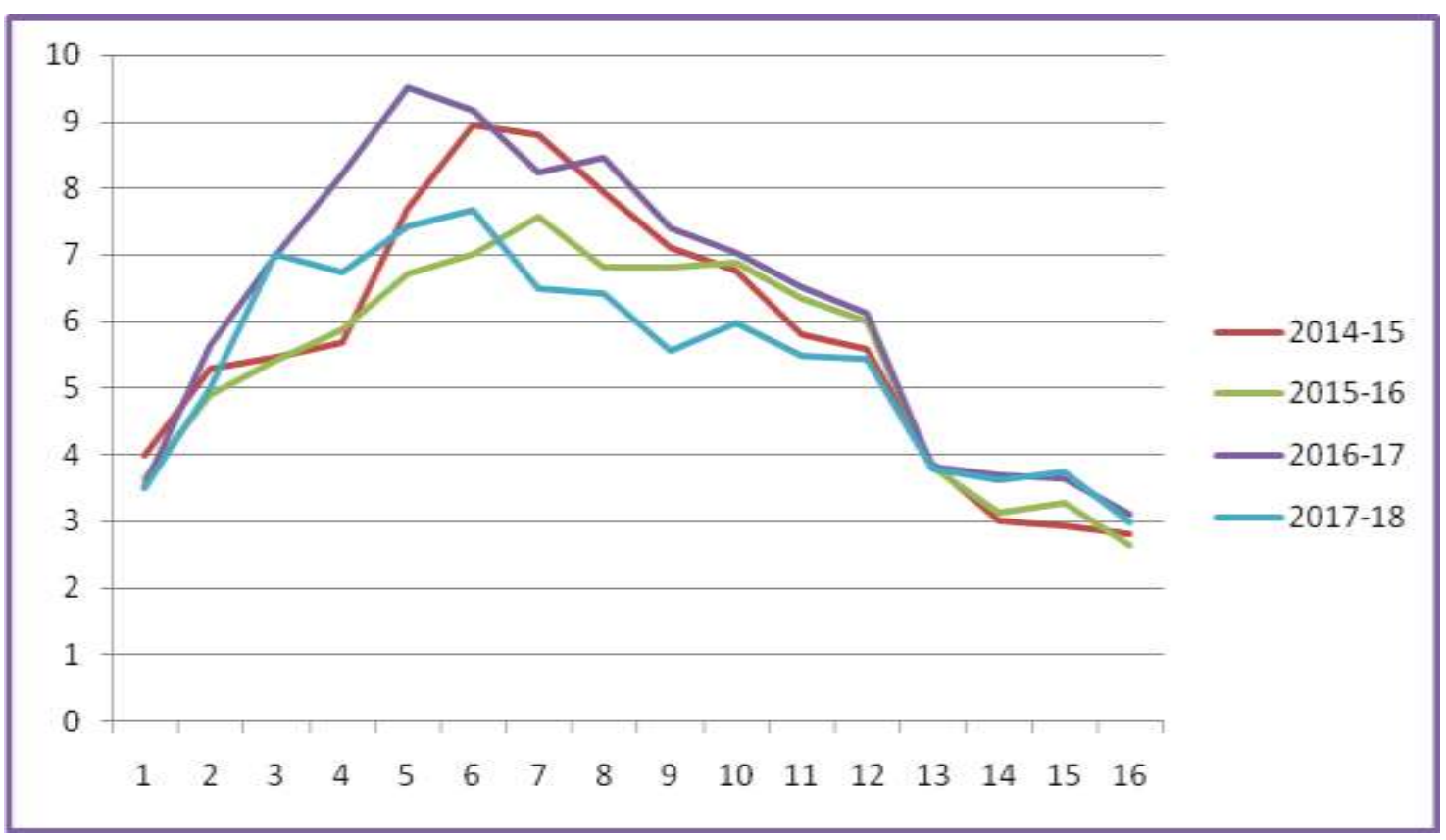

Yousafi et al., (2016) reported that combined regression of moths and fruit infestation during 2012 and 2013 revealed that 19 moths caught in 15 days will result in a 10 per cent fruit infestation which is the ETL for BSFB. The moth catch recording was started from $1^{\text {st }}$ week after their installation in the field and continued throughout the fruiting period of the crop upto 16 weeks from their installation.
In 2014-15, the average total moth catch per trap was 91.80 with peak catch in $6^{\text {th }}$ week after installation of the traps, while, it was 80.95 in $2015-16$ with peak catch in $7^{\text {th }}$ week and in 2016-17 it was 94.56 with peak catch in $5^{\text {th }}$ week and it was 79.24 in $2017-18$ with peak catch in $6^{\text {th }}$ week. Different workers have reported a positive correlation between lepidopteran larval infestation and adult 
catches in traps (Knight, 2001; Walker et al., 2003; Martin et al., 2011). Khalique and Feeroza (2012) studied the relationship between the number of trap catches of Helicoverpa armigera and chickpea infestation and concluded that this study helped in designing IPM strategy well in time.

The cost of cultivation, average gross returns, average net returns and benefit cost ratios calculated in each year were presented in table 2 indicates that adoption of eco-friendly IPM practices resulted in reduction of number of sprays of insecticides, thus reducing the cost of cultivation and improving the net income levels. In 2014-15, through adoption of IPM practice, the cost of cultivation was reduced by Rs. 5000.00 with an increase of Rs. 38075.00 in net returns compared to the farmers practice, the benefit cost ratio was 3.47 compared to 3.34 in farmers practice. In 2015-16, the cost of cultivation was reduced by Rs. 15375.00 with an increase of Rs. 69430.00 in net returns in IPM plots compared to farmers practice. The benefit cost ratio was 3.49 compared to 2.76 in farmers practice. In 2016-17, the cost of cultivation was reduced by Rs. 33080.00 and an increase of Rs. 54630 in net returns in IPM plots compared to farmers practice. The benefit cost ratio was 3.04 compared to 2.29 in farmers practice. In 2017-18 also, the cost of cultivation was reduced by Rs. 14900.00 with an increase of Rs. 41900.00 in net returns in IPM plots compared to farmers practice. The benefit cost ratio was 2.24 compared to 1.79 in farmers practice. The data indicates that by adoption of IPM practices with emphasis on pheromone traps, decision making can be done correctly with respect to the application of insecticides, thus avoiding unnecessary sprays leading to reduction in pest management cost and improving the net returns. Ramamurthy et al., (2010) observed that the analyses of catches in traps are helpful in suggesting appropriate time for pest management. Amin and Gergis (2006) suggested that the integration of lepidopteran moth monitoring with other insect pest control methods can improve environmentally friendly management of insect pests in cotton.

\section{References}

Alam, S.N., Hossain, M.I., Rouf, F.M.A., Jhala, R.C., Patel, M.G., Rath, L.K., Sengupta, A., Baral, K., Shylesha, A.N., Satpathy, S., Shivalingaswamy, T.M., Cork, A. and Talekar, N.S., 2006. Implementation and promotion of an IPM strategy for control of eggplant fruit and shoot borer in South Asia. Tech. Bull. 36. AVRDC

Alpuerto, A.B., 1994. Ecological studies and management of brinjal fruit and shoot borer, Leucinodes orbonalis Guenee. Ind. J. agric. Sci., 52: 391-395.

Amin, A.A. and Gergis, M.F., 2006. Integrated management strategies for control of cotton key pests in Middle Egypt. Agron. Res., 4 (Special issue): 121-128.

AVRDC, 1998. Annual Reports. Asian Vegetable Research and Development Center, Shanhua. Taiwan. Pp. 148.

Baral, K., Roy, B.C., Rahim, K.M.B., Chatterjee, H., Mondal, P., Mondal, D., Ghosh, D. and Talekar, N.S., 2006. Socio-economic parameters of pesticide use and assessment of impact of an IPM strategy for the control of eggplant fruit and shoot borer

CABI, 2007. Crop protection compendium. CAB International. (Available at: http://www. cabicompendium.org/cpc).

Chakraborti, S. and Sarkar, P.K., 2011. Management of Leucinodes orbonalis Guenee on eggplant during the rainy season in India. J. Protect. Res., 51: 325- 328.

Dutta, P., Singha, A.K., Das, P. and Kalita, S., 
2011. Management of brinjal fruit and shoot borer, Leucinodes orbonalis in agro-ecological conditions of West Tripura. Scholarly J. agric. Sci., 1:1619.

Indian Horticulture database, 2015 National Horticultural Board, Ministry of Agriculture, Govt. of India, 127-135

Jagginavar, S.B., Sunitha, N.D. And Biradar, A.P., 2009. Bioefficacy of Flubendiamide 480C against brinjal fruit and shoot borer, Leucinodes orbonalis Guen. Kamtaka J. agric. Sci., 22: 712-713.

Jayaraj, J. and Manisegaran, S., 2010. Management of fruit and shoot borer in brinjal. The Hindu Sci-Tech. Agri. College and Res. Inst. Madurai.

Khalique, A and Feeroza, K., 2012. Oviposition and larval development of Helicoverpa armigera (Hübner) (Lepidoptera: Noctuidae) in relation with chickpea, Cicer arietinum L. (Fabaceae) crop phenology. Pakistan J.Zool., 44:1089-2012.

Knight, A.L., 2001. Monitoring the seasonal population density of Pandemis pyrusana (Lepidoptera: Torticidae) within a diverse fruit crop production area in the Yakima valley, Wa. $J$. entomol. Soc. Br. Columb., 98: 217-225.

Kumar, S. and Dharmendra, S., 2013. Seasonal incidence and economic losses of brinjal shoot and fruit borer, Leucinodes orbonalis Guenee. Agric. Sci. Digest., 33: 98-103.

Latif, M.A., Rahmah, M.M., Islam, M.R. and Nuruddin, M.M., 2009. Survey of arthropod biodiversity in the brinjal field. J. Ent., 6: 28-34.

Latif, M.A., Rahman, M. M. and Alam, M. Z., 2010. Efficacy of nine insecticides against shoot and fruit borer, Leucinodes orbonalis Guenee (Lepidoptera: Pyralidae) in eggplant. $J$. Pestic. Sci., 83: 391-397.
Martin, G.J., Jactel, H. and Diez, J.J., 2011. Pattern and monitoring of Sessia apiformis infestations in poplar plantations at different spatial scales. $J$. appl. Ent., 135: 382-392.

Misra, H.P., 2008. New promising insecticides for the management of brinjal shoot and fruit borer, Lecinodes orbonalis Guenee. Pest Manage. Hort. Ecosys., 14:140- 147.

Naqvi, A. R., Pareek, B.L. and Mitharwal, B.S., 2009. Seasonal incidence of shoot and fruit borer, Leucinodes orbonalis Guenee infesting in hyper arid regions of Rajhistan. J. Insect Sci., 22: 195-198.

Neupane, F.P., 2001. Crop pest and their management ( $4^{\text {th }}$ ed.) (Nepali language). Sajha Prakashan, Pulchwok. Lalitpur, Nepal. Pp. 582.

Ramamurthy, V.V., Akhtar, M.S., Patankar, N.V., Menon, P., Kumar, R., Singh, S. K., Ayri, S., Kumar, S., Parveen, S. and Mittal, V., 2010. Efficiency of different light sources in light traps in monitoring insect diversity. Mun. Ent. Zool., 5: 109-114.

Sharma, D.R., 2002. Bioefficacy of certain insecticide and biopesticides against major pest of brinjal under field condition. M.Sc. thesis. Indian Agric. Res. Inst. New Delhi, India, pp. 160.

Srinivasan, R., 2009. Insect and mite pests on eggplant: a field guide for identification and management. AVRDC Publication No. 09-729. AVRDC - The World Vegetable Center, Shanhua, Taiwan. 64 p.

Talekar, N.S. 2002 Controlling Eggplant Fruit and Shoot Borer A Simple, Safe and Economical Approach. AVRDC pub. \#02-534. International Cooperators' Guide

Vageesh babu S. Hanur, K. Boopal, Vijeth V. Arya, K. N. Srividya, M. S. Saraswathi 2014 Why is management of brinjal shoot and fruit borer, Leucinodes 
orbonalis Guenee, difficult? An examination into the pest's unique feeding behavioral biology. Journal of Entomology and Zoology Studies, 2 (6): 257-260

Walker, G.P., Wallace, A.R., Bush, R., MacDonald, F.H. and Sukling, D.M., 2003. Evaluation of pheromone trapping for prediction of diamondback moth in vegetable brassicas. N. Z. Pl.
Protec., 56: 180-184. Yousafi Q., Muhammad Afzal, Muhammad Aslam and Allah Ditta Abid. 2016. Monitoring of Brinjal Shoot and Fruit Borer (Leucinodes orbonalis Guenee) Adult Populations in Brinjal (Solanum melongena L.) Using Light Traps. Pakistan J. Zool., vol. 48(2), pp. 333343.

\section{How to cite this article:}

Sudha Jacob, P. and Revathi. 2019. Management of Brinjal Shoot and Fruit Borer (Leucinodes orbonalis Guenee) Using Eco-Friendly IPM Strategies in Farmer's Fields of Krishna District of Andhra Pradesh, India. Int.J.Curr.Microbiol.App.Sci. 8(01): 2254-2261.

doi: https://doi.org/10.20546/ijcmas.2019.801.236 